\title{
Perkuliahan Online dengan Aplikasi WhatsApp dalam Program Belajar dari Rumah dimasa Pandemi Covid-19 Fakultas Dakwah Uin Sulthan Thaha Saifuddin Jambi
}

\author{
Ade Novia Maulana, Ahdiyat Mahendra \\ UIN Sulthan Thaha Saifuddin Jambi \\ Email: (ade@uinjambi.ac.id) (ahdiyatmahendra@uinjambi.ac.id)
}

\begin{abstract}
Abstrak: Pandemi Covid-19 telah memaksa manusia mengubah perilaku dalam berbagai aspek dan berbagai bidang, tak terkecuali juga bidang pendidikan. Kebijakan secara mendasar yang dilakukan pemerintah untuk dunia pendidikan dalam masa Pandemic covid-19 adalah adanya kebijakan belajar dari rumah untuk semua jenjang pendidikan. Kebijakan ini mengubah cara lembaga pendidikan melakukan proses pembelajaran, dari semula pembelajaran tatap muka di kelas menjadi pembelajaran jarak jauh. Siap belum siap, pandemi covid-19 memaksa perguruan tinggi yang sebelumnya tidak maksimal menyiapkan dan menerapkan pembelajaran online untuk wajib melaksanakan secara penuh. Mahasiswa serta dosen yang sebelumnya kurang interes melaksanakan pembelajaran online dituntut wajib melakukan perkuliahan online. Karena esensi dari perkuliahan adalah adanya dialog antara mahasiswa dan dosen atau antara mahasiswa dengan mahasiswa, maka dalam pelaksanaan perkuliahan secara online diperlukan aplikasi yang dapat menjamin terlaksananya dialog tersebut. Dari sekian banyak fasilitas internet untuk perkuliahan online, aplikasi whatsapp merupakan salah satu pilihan yang direkomendasikan untuk dipergunakan dalam perkuliahan secara online. Metode yang digunakan dalam penelitian ini adalah metode kualitatif deskriptif. Dalam pengumpulan data penelitian ini melakukan observasi terhadap grup whatsapp. Sedangkan teknik analisis data penelitian ini yaitu deskriptif kualitatif. Hasil penelitian ini adalah fitur whatsaap grup merupakan salah satu alternatif yang baik digunakan dalam proses pembelajaran online. Banyak sekali manfaat yang ditimbulkan dan juga mahasiswa menjadi aktif dalam kelas walaupun tidak melakukan tatap muka.

Kata-kata kunci: perkuliahan online, belajar dari rumah, covid-19.
\end{abstract}

\section{A. Pendahuluan}

Saat ini dunia kesehatan sedang mendapatkan tantangan luar biasa dengan adanya pandemi covid-19. Pandemi Covid-19 adalah peristiwa menyebarnya 
corona virus disease, di seluruh dunia. Wabah penyebaran Covid-19 pertama kali dideteksi di kota Wuhan Provinsi Hubei Tiongkok pada Desember 2019. Setelah itu menyebar luas keseluruh dunia, sehingga ditetapkan sebagai pandemi oleh organisasi kesehatan dunia (WHO) pada 11 Maret 2020. Covid-19 mulai masuk wilayah Indonesia pada akhir bulan Februari 2020 tepatnya di DKI Jakarta, dan dalam waktu yang cepat juga menyebar luas kebeberapa provinsi di Indonesia.

Menyikapi Pandemi Covid-19 memasuki wilayah Indonesia, maka Presiden Republik Indonesia mengeluarkan Keputusan Presiden Nomor 11 Tahun 2020 tertanggal 31 Maret 2020 dan menetapkan pemberlakuan Kedaruratan Kesehatan Masyarakat Corona Virus Disease 2019 (COVID-19) di Indonesia. Penetapan kedaruratan ini diturunkan dalam Peraturan Pemerintah Republik Indonesia Nomor 21 Tahun 2020 Tentang Pembatasan Sosial Berskala Besar Dalam Rangka Percepatan Penanganan Corona Virus Disease 2019 (COVID-19). Sebelumnya Kepala Kepolisian Negara Republik Indonesia sudah mengeluarkan Maklumat Kapolri Nomor Mak/2/III/2020 Tentang Kepatuhan Terhadap Kebijakan Pemerintah dalam Penanganan Penyebaran Virus Corona (COVID-19), tertanggal 19 Maret 2020. Dengan ditetapkannya Kedaruratan Kesehatan dan peraturan terkait lainnya maka telah memaksa semua aktivitas harus mengikuti protokol kesehatan yang ditetapkan oleh Negara. Penetapan kedaruratan Pandemi Covid-19 telah mengubah berbagai perilaku kehidupan di dunia, termasuk diantaranya adalah dunia pendidikan. Sehingga pada akhirnya Kementrian Pendidikan Republik Indonesia mengeluarkan kebijakan pengelolaan pendidikan dalam pandemic Covid-19 dengan kebijakan Belajar dari Rumah.

Belajar dari rumah merupakan salah satu alternatif pembelajaran yang dapat dilaksanakan oleh pendidik dan peserta didik. Namun hal ini tentu saja memiliki konsekuensi yang harus dipenuhi agar pelaksanaan kegiatan tersebut berjalan dengan baik, seperti kesiapan dan ketersedian media yang dapat mendukung proses pembelajaran. Platform pembelajaran yang dapat diakses 
pada saat ini tentu cukup memadai dan dapat diakses dengan mudah, salah satunya adalah media Whatsapp.

Penelitian ini bertujuan untuk melihat bagaimana pemanfaatan dosen dan mahasiswa Fakultas Dakwah UIN Sulthan Thahasa Saifuddin Jambi dalam menggunakan aplikasi WhatsApp dalam perkuliahan berbasis Belajar Dari Rumah serta bertujuan untuk melihat sisi-sisi yang perlu dikembangkan dalam pengembangan penggunaan aplikasi pembelajaran berbasis online.

Metode penelitian yang digunakan adalah kualitatif, yang bermaksud untuk mendeskripsikan dan menganalisa fenomena, peristiwa, aktivitas, sikap, persepsi, dan pemikiran orang secara individual atau kelompok, serta untuk memahami fenomena apa yang dialami subjek penelitian, baik perilaku, persepsi, motivasi, tindakan, dan lain-lain secara holistik. ${ }^{1}$

Penelitian ini menggunakan teknik pengumpulan datanya yaitu observasi melalui pengamatan terhadap aktivitas chat di dalam Grup WA serta dokumentasi. Selanjutnya, teknik analisis data yang dilakukan adalah deskriptif kulitatif. Analisis deskriptif yang dimaksud dalam penelitian ini adalah untuk memberikan informasi mengenai data yang diamati agar bermakna.

\section{B. Aplikasi WhatsApp}

Keberadaan media sosial WhatsApp merupakan salah satu bukti perkembangan teknologi dan komunikasi yang harus disikapi dengan positif. Whatsapp merupakan aplikasi mobile yang dapat mendukung berbagai macam fitur komunikasi basis data internet yang memungkinkan bagi penggunannya untuk berbagi berbagi macam hal dan berkomunikasi dengan beberapa variasi. Aplikasi WhatsApp menjadi aplikasi yang paling diminati kedua, yang digunakan oleh berbagai macam kelompok masyarakat di Indonesia, tak terkecuali oleh

${ }^{1}$ Sugiyono, Metode Penelitian Pendidikan Pendekatan Kuantitatif, Kualitatif, Dan $R \& D$ (Bandung: Alfabeta, 2012). 
para akademisi perguruan tinggi seperti mahasiswa dan dosen di Fakultas Dakwah Univeristas Islam Negeri Sulthan Thaha Saifuddin Jambi.

Pemanfaatan WhatsApp Grup di lingkungan kampus ini sangat tinggi. Hampir semua dosen menggunakan whatsapp grup sebagai alat komunikasi mereka dalam penerapan kuliah online ini. Para mahasiswa diharapkan masuk dan terlibat selama proses perkuliahan berlangsung. Penggunaan whatsapp grup ini dilakukan oleh pihak kampus guna sebagai media komunikasi untuk mahasiswa dan dosen agar perkuliahan tetap efektif walaupun tidak tatap muka langsung. Whatsapp merupakan salah satu media sosial yang saat ini banyak digunakan sebagai penyampaian pesan baik oleh individu maupun kelompok untuk kepentingan bersosialisasi. ${ }^{2}$ Keberadaan WhatsApp Messenger tidak terlepas dari generasi digital yang selalu menginginkan adanya pemutakhiran terhadap berbagai teknologi berbasis internet. Namun sejauh mana penggunaan Whatsapp oleh penggunanya maka dari latar belakang tersebut di atas maka rumusan masalah penelitian ini yaitu bagaimana proses dan pemanfaatan Whatsapp sebagai media komunikasi kuliah online Fakultas Dakwah Universitias Islam Negeri Sulthan Thaha Saifuddin Jambi. Sedangkan tujuan penelitian ini untuk mengetahui bagaimana proses dan pemanfaatan Whatsapp sebagai media komunikasi kuliah online Fakultas Dakwah Universitas Islam Negeri Sulthan Thaha Saifuddin Jambi angkatan tahun 2019.

\section{Pembentukan Grup Whatsapp dan Hasil Perkuliahan}

Pada bagian ini, peneliti akan memaparkan beberapa hal, diantaranya: 1 . Proses pembentukan grup Whatsapp dan proses perkuliahan atau pemberian materi di dalam Grup WA yang telah dibentuk, 2. Hasil perkuliahan online. Adapun analisisnya sebagai berikut:

2 Tugiyo Aminoto and Rahma Dani, "Pengembangan Model Diskusi Berbasis Whatsapp Untuk Meningkatkan Pemahaman Konsep Pada Mata Kuliah Fisika Statistik," EduFisika 3, no. 01 (June 30, 2018): 24-30. 


\section{Proses pembentukan grup Whatsapp}

Universitas Islam Negeri Sulthan Thaha Saifuddin Jambi merupakan salah satu universitas yang memberlakukan sistem kuliah online. Pihak masing-masing jurusan telah melaksanakan kuliah online dengan memanfaatkan berbagai aplikasi. Seperti yang dilakukan oleh Fakultas Dakwah angkatan 2019 dalam penerapan kuliah online ini dengan menggunakan aplikasi Whatsapp grup. Dengan penggunaan fitur whatsapp grup ini perkuliahan tetap berjalan efektif walaupun tidak bertatap muka langsung.

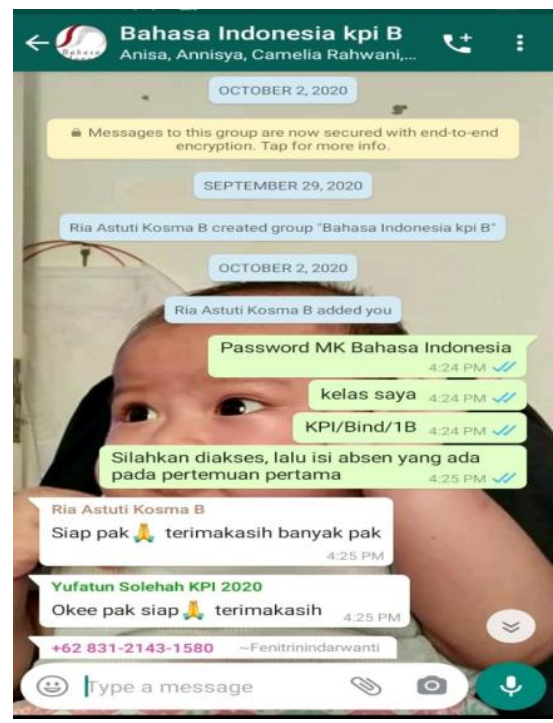

Gambar 1.

Gambar 1 di atas merupakan salah satu whatsapp grup yang dibuat untuk proses perkuliahan online. Ketua kelas membuat grup whatsapp, setelah itu mengundang mahasiswa dan dosen dimatakuliah tersebut. 


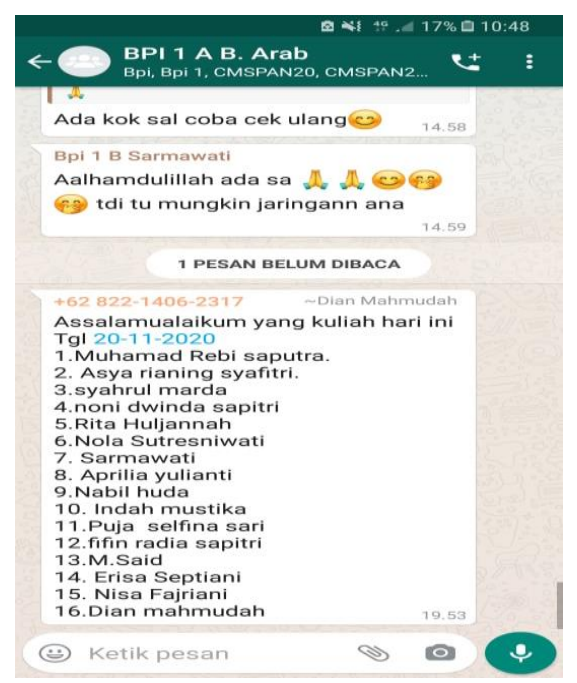

Gambar 2.

Gambar 2 menunjukkan proses absensi yang dilakukan di whatsapp grup. Saat jam telah menunjukan waktu dimulai perkuliahan, dosen akan melakukan absensi terlebih dahulu. Setelah semua mahasiswa telah melakukan absen maka setelah itu, dosen akan mengirimkan file materi perkuliahan dan menerangkan materi perkuliahan.

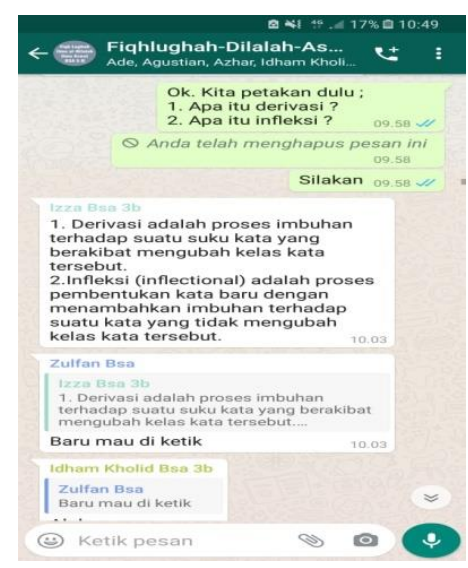

Gambar 3.

Gambar 3 di atas memperlihatkan bahwa setelah dosen menjelaskan materi maka mahasiswa diberi kesempatan untuk bertanya dan menanggapi dari materi yang diberikan. Mahasiswa dituntut untuk aktif dalam melakukan perkuliahan. 
Dalam proses perkuliahan online ini pihak Fakultas Dakwah Universitas Islam Negeri Sulthan Thaha Saifuddin Jambi menganut paradigma yang memposisikan mahasiswa sebagai center. Sesi pelajaran meliputi absensi, penyampaian materi pembelajaran, tanya jawab, memberikan tanggapan, dan tugas. Hal ini untuk memastikan bahwa mahasiswa memiliki acuan utama sebagai bahan pembacaan, pemahaman, dan pelaksanaan praktik latihan. Adapun sesi interaktif dimaksudkan agar tercipta iklim dinamik yang kondusif serta membuka isolasi agar mahasiswa melakukan kemitraan dan kolaborasi secara terbuka.

\section{Hasil Perkuliahan Online menggunakan Aplikasi Whatsapp}

Sebagai capaian hasil pembelajaran daring, para mahasiswa telah aktif dalam proses pembelajaran. Yang sebelum proses daring ini para mahasiswa banyak yang kurang aktif tetapi dengan diadakan proses pembelajaran daring ini mahasiswa aktif di dalam Whatsapp grup. Mahasiswa mulai berani memberikan pendapat dan juga pertanyaan dari penyampaian materi yang dilakukan oleh masing-masing dosen. Dalam proses pembelajaran online ini juga pencapaian absensi dan waktu kehadiran dari masing-masing mahasiswa juga meningkat. Bila sebelumnya para mahasiswa jarang hadir dan terlambat datang masuk kelas, proses daring ini membuat mahasiswa dapat mengikuti kuliah online tepat waktu. Hal tersebutlah merupakan salah satu hasil dari pemanfaatan penggunanan fitur Whatapp grup. Mahasiswa dapat berkomunikasi lebih mudah dengan dosen untuk berdiskusi maupun bertanya baik secara umum di grup kelas maupun dengan menghubungi dosen secara pribadi. (Sukrillah et al., 2018).

\section{Penutup}

Dalam proses perkuliahan online ini pihak Fakultas Dakwah Universitas Islam Negeri Sulthan Thaha Saifuddin Jambi menganut paradigma yang memosisikan mahasiswa sebagai center. Sesi pelajaran meliputi absensi, 
penyampaian materi perkuliahan, sesi tanya-jawab dan tanggapan, serta tugas. Sebagai capaian hasil pembelajaran online ini, para mahasiswa telah aktif dalam proses pembelajaran.

Kesempatan diskusi yang semakin luas dengan optamalisasi penggunaan WA ini meningkatkan semangat belajar mahasiswa. Mahasiswa dapat langsung bertanya jika kurang paham dalam topik tertentu. WhatsApp dapat membantu siswa memperoleh pengetahuan, berdiskusi dan belajar secara aktif, dan berinteraksi dengan mudah daripada pembelajaran tradisional. Penggunaan aplikasi whatsaap grup sebagai sarana kuliah online sangat bermanfaat dan membantu dalam proses berkomunikasi, memberi dan menerima informasi. Penyampaian dan penyebaran berita yang sangat cepat membuat salah satu keunggulan yang diberikan oleh aplikasi whatsapp.

\section{Daftar Pustaka}

Adijaya, N., \& Santosa, L. P. (2018). Persepsi Mahasiswa dalam Pembelajaran Online. Wanastra. https://doi.org/2579-3438 Aminoto, T., \& Dani, R. (2018).

Aminoto, Tugiyo, and Rahma Dani. "Pengembangan Model Diskusi Berbasis Whatsapp Untuk Meningkatkan Pemahaman Konsep Pada Mata Kuliah Fisika Statistik." EduFisika 3, no. 01 (June 30, 2018): 24-30.

Ansam, H. (2020). Antisipasi Virus Corona, 56 Kampus Di Indonesia Putuskan Kuliah Online. Goriau.Com. https://www.goriau.com/berita/baca/a ntisipasi-virus-corona-56-kampus-diindonesia-putuskan-kuliahonline.html Carr, C. T., \& Hayes, R. A. (2015).

Carr, C. T., \& Hayes, R. A. (2015). Social Media: Defining, Developing, and Divining. Atlantic Journal of Communication, 23(1), 46-65. https://doi.org/10.1080/15456870.201 5.972282Social Media: Defining, Developing, and Divining. Atlantic Journal of Communication. https://doi.org/10.1080/15456870.201 5.972282 
Darmalaksana, W., Hambali, R. Y. A., Masrur, A., \& Muhlas. (2020). Analisis Pembelajaran Online Masa WFH Pandemic Covid-19 sebagai Tantangan Pemimpin Digital Abad 21. UIN Sunan Gunung Djati Bandung.

Grover, S., Garg, B., \& Sood, N. (2020). Introduction of case-based learning aided by WhatsApp messenger in pathology teaching for medical students. Journal of Postgraduate Medicine. https://doi.org/10.4103/jpgm.JPGM_2 $-19$

Hastuti, R. K. (2020). Corona RI 17 April, 5.923 Positif, 520 Meninggal, 607 Sembuh. Cnbcindonesia.Com. https://www.cnbcindonesia.com/news /20200417151135-4-152745/coronari-17-april-5923-positif-520meninggal-607-sembuh

Laode Anhusadar. (2020). PERSEPSI MAHASISWA PIAUD TERHADAP KULIAH ONLINE DI MASA PANDEMI COVID 19. KINDERGARTEN: Journal of Islamic Early Childhood Education. https://doi.org/http://dx.doi.org/10.24 014/kjiece.v3i1.9609

Prajana, A. (2017). PEMANFAATAN APLIKASI WHATSAPP UNTUK MEDIA PEMBELAJARAN DALAM LINGKUNGAN UIN AR-RANIRY BANDA ACEH. Cyberspace: Jurnal Pendidikan Teknologi Informasi. https://doi.org/10.22373/cs.v1i2.1980

Pratama, Ryan Angga. "KULIAH MELALUI WHATSAPP (KULWAPP)." De Fermat : Jurnal Pendidikan Matematika 2, no. 1 (June 30, 2019): 17-27.

Sugiyono. Metode Penelitian Pendidikan Pendekatan Kuantitatif, Kualitatif, Dan R \& D. Bandung: Alfabeta, 2012.

Sukrillah, A., Ratnamulyani, I. A., \& Kusumadinata, A. A. (2018). Pemanfaatan Media Sosial Melalui Whatsapp Grup Fei Sebagai Sarana Komunikasi. Jurnal Komunikatio. https://doi.org/10.30997/jk.v3i2.919

Suryadi, E., Ginanjar, M. H., \& Priyatna, M. (2018). Penggunaan Sosial Media Whatsapp Pengaruhnya Terhadap Disiplin Belajar Peserta Didik Pada Mata Pelajaran Pendidikan Agama Islam (Studi Kasus Di SMK Analis Kimia 
YKPI Bogor). Edukasi Islami : Jurnal Pendidikan Islam.

https://doi.org/10.30868/ei.v7i01.211 